\title{
EFFICIENCY OF RYE BIOMASS ON OIL HYDROCARBON BIODEGRADATION
}

\author{
G. Giedraityte $\dot{e}^{1}$ \\ L. Kalèdien $\dot{e}^{1^{*}}$ \\ R. Liužinas ${ }^{2}$ \\ Vilnius University ${ }^{1}$, Lithuania \\ Public Agency „Soil remediation technologies“,Vilnius ${ }^{2}$, Lithuania
}

\begin{abstract}
The majority of the plants secrete their enzymes in the soil, where they can decompose various organic compounds. Extra cellular plant enzymes can be effective against a number of contaminants. To estimate the plants, their enzymes and micro-organism effect on hexadecane content in the soil, the sterile soil samples was amended with 0.5 $\%$ hexadecane and sowed with accordingly prepared rye seeds. Till increasing the quantity of micro-organisms and the formation of rye seedlings, hexadecane content remained practically unchanging in all samples. After 21 days hexadecane content in the soil with rye seedlings was about $5 \%$ of the contributed content. The intrinsic soil processes through 21 days to shrank the hexadecane content in the soil without rye seedlings up to $17 \%$. Oxidases, catalases and peroxidases were detected in rye biomass during all test period. As shown by the results, polyphenoloxydases were detected only in root biomass, the early germs of germination and roots formation stages.
\end{abstract}

\section{KEYWORDS}

Phytoremediation, enzyme, micro-organisms

\section{INTRODUCTION}

Phytoremediation is a quite novel technique to clean polluted soils using plants. Plants affect the water balance of a site; they change redox potential and $\mathrm{pH}$, and stimulate microbial activity of the soil. Currently, phytoremediation is used for treating many classes of contaminants including oil hydrocarbons, chlorinated solvents, pesticides, explosives, heavy metals and other. There are numerous mechanisms by which plants may remediate contaminated sites. Many plant enzymes appear to play an important role in xenobiotic degradation, including dehydrogenases, peroxidases, nitroreductases, dehalogenases and others mono- and dioxygenases $[4,11,15]$. The majority of these plants secrete their enzymes in the soil, where they can decompose various organic compounds. The enzymes are involved in the xenobiotics digestion, after the plants to soak up a simple diffusion path. Pollutant intake leads to close contact with detoxicated plant enzymes, which are located in cell citozol. Plant organs are the further https://doi.org/10.15626/Eco-Tech.2010.088 
transformation of these compounds, conjugation and the transfer of the various plant tissues. Later, they may even be evaporated [1]. Some of these enzymes appear to be naturally released into the soil, where they are capable of degrading organic pollutants ranging from solvents to explosives [17].

Innovative, new techniques are required for cleaning up hydrocarbon-contaminated environments. Our interest focuses on the interaction of oil hydrocarbons with plant biomass enzymes in soil. The processes that favour phytoremedation may be optimized by the choice of plant species. The evidence has been mainly based on higher plant species, in particular crop plant species. The aim was to assess the impact of the plant enzyme degradation of oil hydrocarbons.

\section{MATERIALS AND METHODS}

The laboratory tests were performed in plastic boxes. For control rye seeds were twice washing with $70 \%$ ethanol and overspreading in plastic boxes with sterile soil $(25 \%$ $\mathrm{w} / \mathrm{w})$. Rye seeds were germinated at room temperature $\left(20 \pm 2^{\circ} \mathrm{C}\right)$. Plants were harvested 20 days after seedling emergence. The part of the rye shoots from control plastic boxes were cut and twice washed with sterile distilled water and mashed up. The $2.5 \%$ rye mash prepared from rye shoots was added to mineral salt medium M9 without carbon source [12]. The medium was supplemented with $0.5 \%$ hexadecane. Control was prepared with mineral M9 salt medium supplemented with $2.5 \%$ preheated rye mash and with $0.5 \%$ hexadecane. Biomass was heated for 48 hours at $60^{\circ} \mathrm{C}$. The flasks were incubated at room temperature for 21 days. All experiments were performed in triplicate. To estimate the plant and micro-organism effect on hexadecane content in the soil, the soil samples were sieved $(2 \mathrm{~mm})$, steriled at $121^{\circ} \mathrm{C}$ for 1.5 hours. Before application, one part of the soil samples was amended with $0.5 \%$ hexadecane and sowed with $70 \%$ ethanol washed rye seeds. Every 7 day three replicate boxes and flasks were collected for enzymes, micro-organisms and hexadecane content assays. Hexadecane extraction and gravimetric measurements were used to determine the concentration in experiments [6].

For qualitative enzyme assays the rye $20-30 \mathrm{~cm}$ shoots and the roots from every box and flask were cut and mashed up. The filter paper discs soaked with test reagent, N, N, N', N'-tetra-ethyl-p-phenylenediamine dihydrochloride were used to oxidase detection. The oxidase test is a test used to determine cytochrome c oxidases. The reagent is a dark blue to maroon colour when oxidized and colourless when reduced [2]. Catalase peroxidase test was done as advocated by Bogen (1957). $2.0 \mathrm{ml}$ of a freshly prepared mixture of equal volumes of $0.2 \%$ catechol and $1 \%$ hydrogen peroxide solutions in distilled water was poured on the rye mash. Evolution of bubbles within 3 to 5 minutes was taken as an indication of the presence of catalase. If the colonies turned brown or black within 45 to 60 minutes they were termed as peroxidase positive. The filter paper strips soaked with $0.5 \mathrm{M}$ catechol solution were used for polyphenol oxidase detection [9]. Oxygen-dependent formation of o-quinones leads to the formation of brown and black pigmented polymers. 
The micro-organism cultures were obtained by standard serially diluting method. Serially diluted samples were plated on plate count agar medium (Oxoid) and nutrient broth agar (BIOKAR) for bacteria. Mitosporic fungi were isolated on Czapek agar (Merck).

\section{RESULTS AND DISCUSSION}

Plants perform phytoremediation by multiple processes including metabolism, volatilization, and sequestration followed by harvesting. Additionally, plants exude compounds and enzymes that facilitate the breakdown of pollutants $[8,10,13]$, and stimulate microbial biodegradation in the rhizosphere. The main plant enzymes involved in degradation and detoxification of organic pollutants, including petroleum products, belong to oxidoreductase class. It is established that a large proportion of these enzymes found in plant root exudates distinction along with the other metabolites [14]. Extra cellular plant enzymes including laccases, dehalogenases, nitroreductases, peroxidases and hydrolases can be effective against a number of contaminants.

Before starting to investigate the plant influence on the oil hydrocarbon degradation by selected compounds we tested their volatility. The high volatility and low boiling point of organic compounds have a negative impact on the reliability of research results. Therefore, the tests were to choose less volatile oil hydrocarbons, choicely decane, hexadecane, xylene, naphthalene. The first test was checked at the beginning of hydrocarbon evaporation intensity. After 7 days the control flasks found that xylene decreased by an average of $96.6 \%$, decane $-70.5 \%$, naphthalene - $26.4 \%$. Hexadecane average remained in flasks to $95 \%$. Therefore, for further research has been selected hexadecane of.

As shown the studies the number of micro-organisms began to rise for the second day in the sterile soil sown with ethanol washed rye seeds (Fig. 1.) 


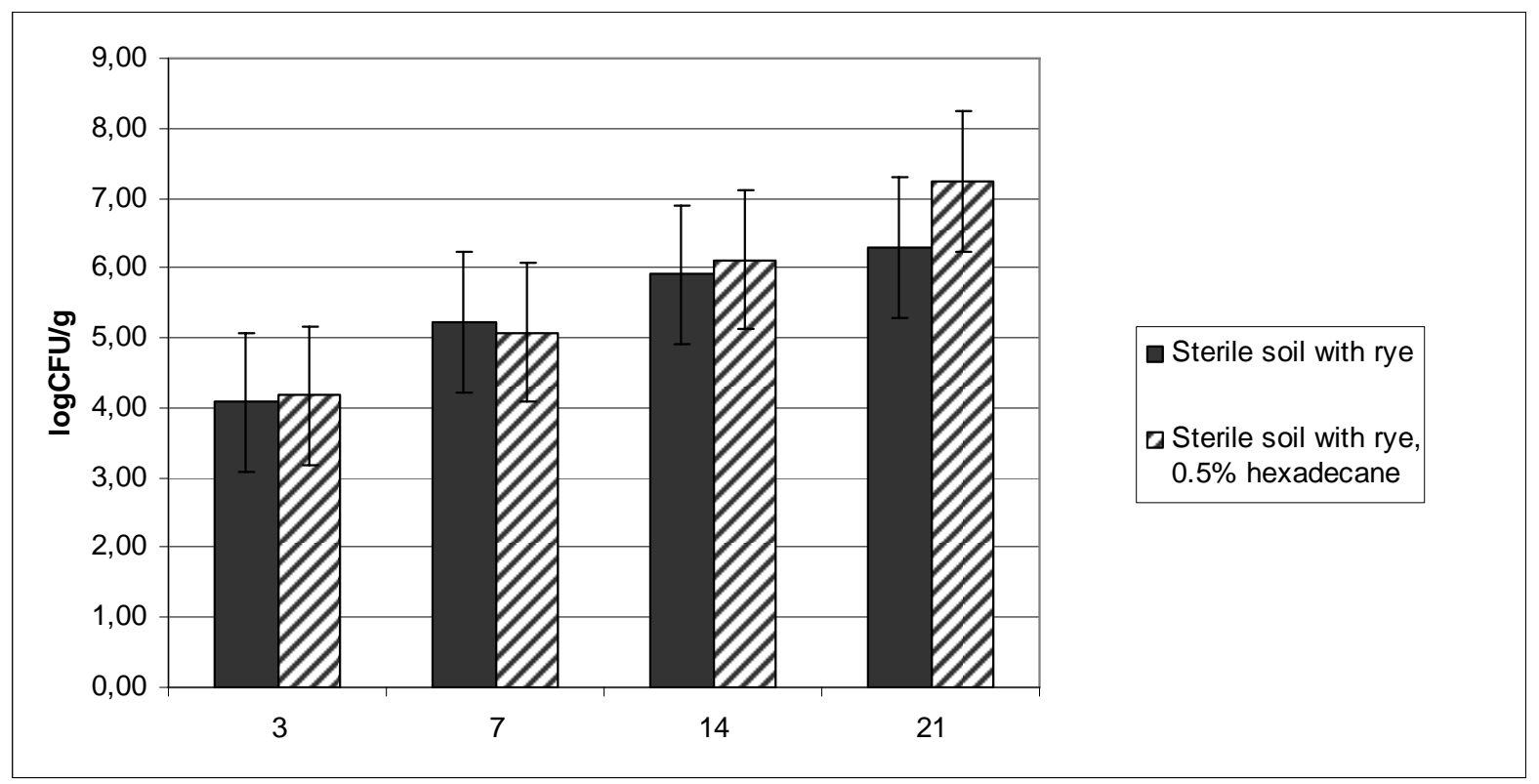

Figure 1. Alteration of micro-organism number in sterile soil with rye (control) and sterile soil with rye and $0.5 \%$ hexadecane.

The experiment sterility was not wholly established under indoor conditions. Within 7 days the number of micro-organisms in all variants achieved of $\log 5$ colony forming units (CFU)/1g soil. The microbe number intensively increased in soil with hexadecane, and achieved $\log 7 \mathrm{CFU} / \mathrm{lg}$. Aside from the uptake of compounds with subsequent metabolism, plants frequently participate indirectly by changing the soil conditions so that soil micro-organisms can degrade pollutants [14]. Plants affect the water balance, $\mathrm{pH}$ of a site, and stimulate microbial activity of the soil. These indirect influences may accelerate compound's degradation in the root zone. These processes include modification of the physical and chemical properties of contaminated soils, releasing root exudates, thereby increasing organic carbon, improving aeration, effecting cometabolic microbial and plant enzymatic transformations of pollutants.

Through the first 7 days, till increasing the quantity of micro-organisms and the formation of rye seedlings, hexadecane content remained practically unchanging in all samples (Fig.2). Obviously, the formation of rhizosphere time had an impact on the decrease of hexadecane quantity in soil. On 14 day the hexadecane amounted to $43 \%$ in soil, to $31 \%$ in soil with rye seeds. After 21 days the hexadecane content in the soil with rye seedlings represented about $5 \%$ of the contributed content. The intrinsic soil processes through 21 days to shrank the hexadecane content in the soil without rye seedlings up to $17 \%$ (Fig. 2). 


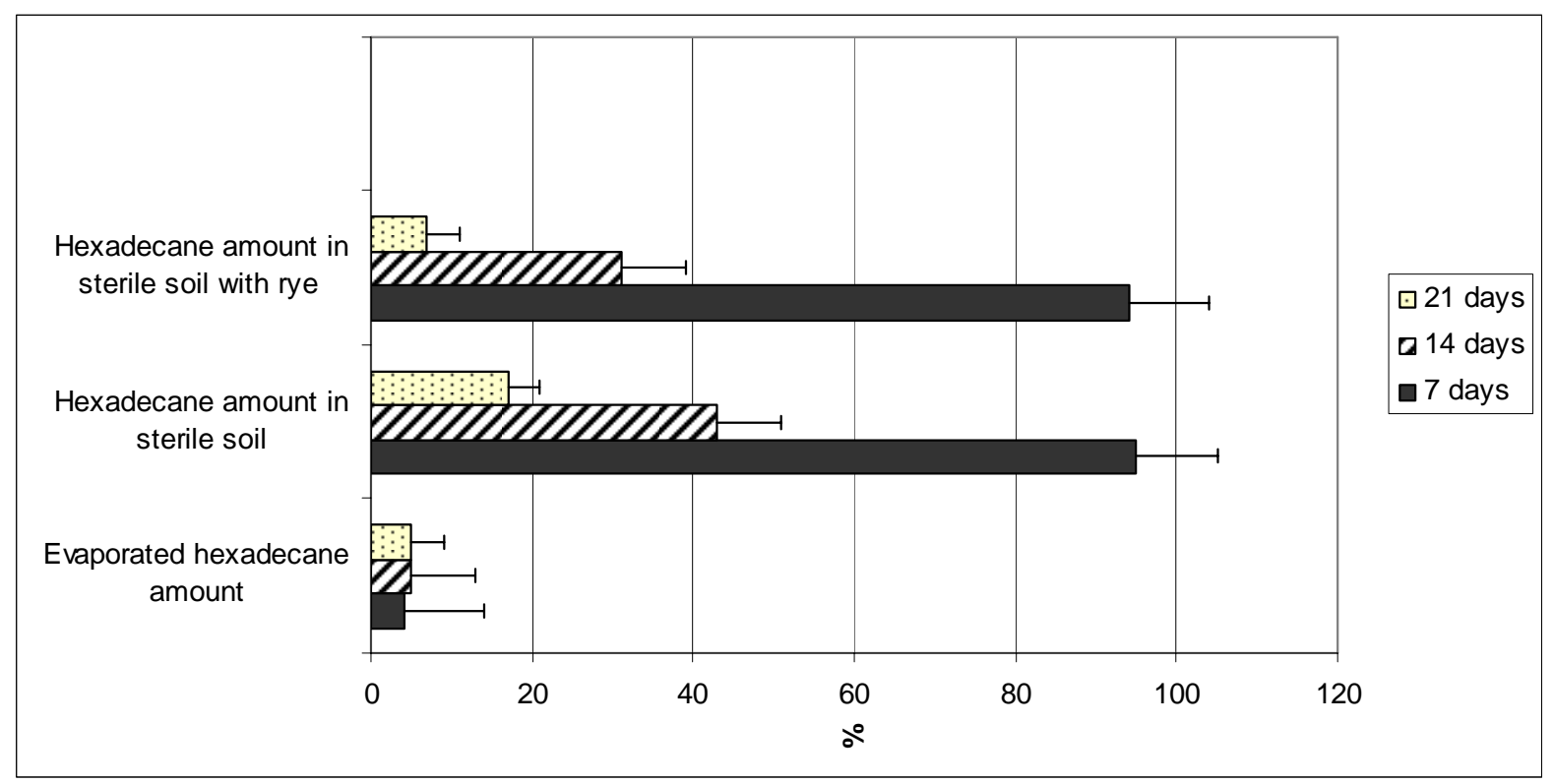

Figure 2. Variation of hexadecane amount in sterile soil with rye.

Hexadecane content in the mineral liquid medium with rye shoot biomass decreased in the same way as in the soil with hexadecane. However, the decrease has been recorded during the first 7 days (Fig. 3.) As shown by the results hexadecane volume in liquid medium with rye shoot biomass decreased from $98 \%$ to $5 \%$ to compare with $82 \%$ in liquid medium with preheated rye shoot biomass.

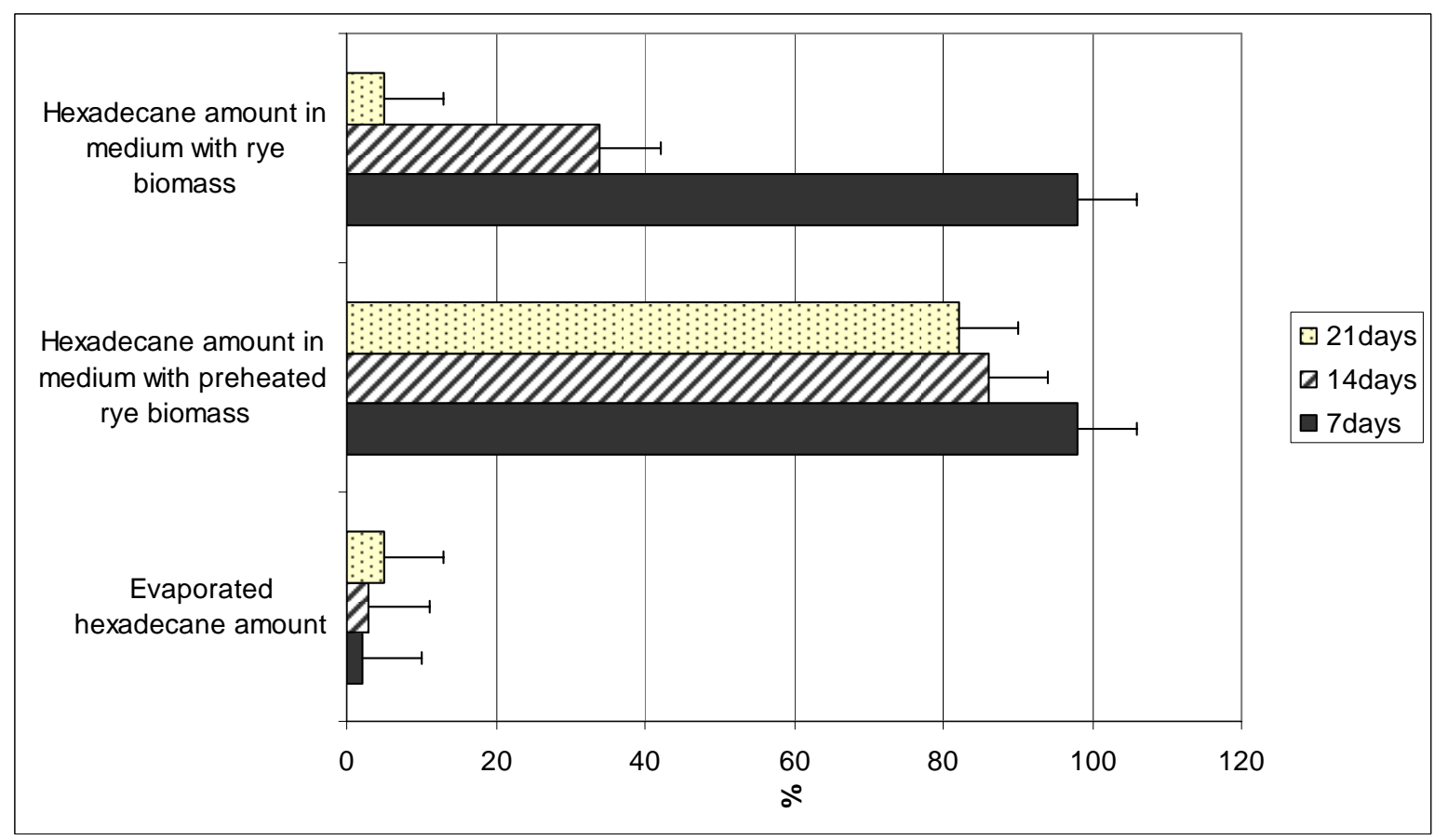

Figure 3. Reduction of hexadecane content in the mineral liquid medium with rye shoot biomass. 
Organic toxicants decomposition processes are closely related to many aspects of higher plants cellular metabolism. According to catalyzed reactions they are directly or indirectly participating in detoxification process. Ecologically the most advantageous pathway of organic contaminants transformation in plants is their oxidative degradation. In higher plants mainly the following enzymes are responsible for this process: cytochrome P450-containing monooxygenese, peroxidase and phenoloxidase [3]. As expected, the plant enzymes may affect the degradation of petroleum hydrocarbons. Within all test time the rye shoot and root biomasses were studied in the specific enzymatic activity, which may affect the hexadecane degradation. Data present in Tables 1 and 2.

Table 1. Enzymatic activity of the rye shoots biomass in mineral liquid media with $0.5 \%$ hexadecane.

\begin{tabular}{l|c|c|c|}
\hline \multirow{2}{*}{ Enzyme } & \multicolumn{3}{|c|}{ Days } \\
\cline { 2 - 4 } & 7 & 14 & 21 \\
\hline Oxidases & + & + & + \\
\hline Catalase & + & + & W \\
\hline Peroxidase & + & - & - \\
\hline Polyphenol oxydases & - & & + \\
+ & & & \\
\hline & & & \\
- &
\end{tabular}


Table 2. Enzymatic activities of the rye shoot's and root's biomass in soil with hexadecane.

\begin{tabular}{|l|c|c|c|c|c|c|}
\hline \multirow{3}{*}{ Enzyme } & \multicolumn{5}{|c|}{ Soil with 0.5\% hexadecane } \\
\cline { 2 - 7 } & \multicolumn{5}{|c|}{ Shoot's biomass } & \multicolumn{3}{c|}{ Root's biomass } \\
\cline { 2 - 7 } & \multicolumn{5}{|c|}{ Days } \\
\cline { 2 - 7 } & 7 & 14 & 21 & 7 & 14 & 21 \\
\hline Oxidases & + & + & + & $\mathrm{n}^{*}$ & + & + \\
\hline Catalase & + & + & + & $\mathrm{n}^{*}$ & + & + \\
\hline Peroxidase & + & + & + & $\mathrm{n}^{*}$ & + & + \\
\hline $\begin{array}{l}\text { Polyphenol } \\
\text { oxydases }\end{array}$ & - & - & - & $\mathrm{n}^{*}$ & + & $\mathrm{w}$ \\
\hline
\end{tabular}

$n^{*}$ - insufficiently formed root system

+ - positive

- - negative

w - weakly positive

Oxidases, catalases and peroxidases were detected in rye biomass during the all test period. Similar results are derived from the study of enzyme activity in soil and in liquid media. As shown by the results, polyphenol oxydases were detected only in root biomass, the early germs of germination and roots formation stages. Plant enzyme activity my increases in response to toxic action of contaminants. Catalase uses hydrogen peroxide to oxidise toxins including phenols, formic acid, formaldehyde and others [5]. Peroxidases catalyze a number of free radical reactions. Alternatively, the compound that is directly oxidized by the enzyme further oxidizes other organic compounds, including xenobiotics. The great majority of organic contaminants in plants are oxidized by peroxidases [16]. In literature the participation of plant peroxidases in hydroxylation reactions of xenobiotics has been widely discussed [7]. Phenol oxidases actively participate in the oxidation of xenobiotics of aromatic structure. These compounds activate molecular oxygen by forming oxygen radicals, such as super oxide anion radical and hydroxyl radical. Formation of these radicals enables phenoloxidase to participate in contaminants degradation processes also by co-oxidation mechanism. As a result of functional group introduction molecule of transformed contaminants becomes easily accessible for further enzymatic transformation. The detection of plant enzymes 
secreted in sterile soil with hexadecane argues that hexadecane can stimulate theirs secretion.

Many of the plant xenobiotic enzymes are constitutive, unlike microbial enzymes, which are inductive, requiring prior induction for action, since extensive metabolism of numerous xenobiotics was observed in plant cell cultures without any prior induction treatment [4]. Thus plants as tools of bioremediation of contaminants have gained importance.

\section{CONCLUSIONS}

Extra cellular plant enzymes including catalases, peroxidases and oxidases were detect in rye shoot mash. However, as shown by the results, polyphenoloxydases were detected only in root biomass, the early germs of germination and roots formation stages. Obviously, the formation of rhizosphere time had an impact on the decrease of hexadecane quantity in soil. Till increased the quantity of micro-organisms and the formation of rye seedlings, hexadecane content remained practically unchanging in all tested soil samples. After 21 days hexadecane content in the soil with rye seedlings was about $5 \%$ of the contributed content. The hexadecane content in the soil without rye seedlings through 21 days shrank up to $17 \%$. As shown by the results hexadecane volume in liquid medium with rye shoot biomass decreased from $98 \%$ to $5 \%$ to compare with $82 \%$ in liquid medium with preheated rye shoot biomass.

Use of plant enzyme treatment and the application of this bioremediation technology are currently at the stage of laboratory research. But today there is no doubt that the plant enzymes may affect the degradation of organic pollutants and the development of phytoremediation technologies may be promising soil rehabilitation.

\section{REFERENCES}

[1] Campos, V.M., Merino, R., Casado, L., Pacios, F., Gómez, L. 2008. Review. Phytoremediation of organic pollutants. Spanish Journal of Agricultural Research. Vol. 6 (Special issue). P. 38-47

[2] Collins, C.H., Lyne, P.M., Grange, J.M., Falkinham, J.O. 2004. Oxidase test. In: Collins C.H., Lyne P.M. (eds.) Microbiological Methods. 8th ed. Arnold. London. P. 97-98.

[3] Didierjean, L., Gondet, L., Perkins, R., Lau, S-M.C., Schaller, H., O'Keefe, D.P., Werck-Reichhart, D. 2002. Engineering herbicide metabolism in tobacco and Arabidopsis with CYP76B1, a cytochrome P450 enzyme from Jerusalem artichoke. Plant Physiology. Vol. 130. P. 179-189

[4] Dietz, A.C., Schnoor, J.L. 2001. Advances in phytoremediation. Environmental Health Perspectives. Vol.109. P. 163-168. 
[5] Feierabend, J. 2005. Catalases in plants: molecular and functional properties and role in stress defence. In: N.Smirnoff (ed.). Antioxidant and reactive oxygen species in plant. Blackwell Publishing Ltd. Oxford, UK. P. 101 - 132

[6] Kimura, B., Murakami, M., Fujisawa, H. 1989. Heavy oil degradation by bacteria isolated from the sea water in oil polluted Bisan Seto. Nippon Suisan Gakkaishi. Vol. 55(12). P. 2173-2177.

[7] Kvesitadze, E., Sadunishvili, T. and Kvesitadze, G. 2009. Mechanisms of Organic Contaminants Uptake and Degradation in Plants. Proceedings of World Academy of Science, Engineering and Technology. Vol. 55. P. 458-468

[8] Li, J.H., Gao, Y., Wu, S.C., Cheung, K.C., Wang, X.R., Wong, M.H. 2008. Physiological and biochemical responses of rice (Oryza Sativa L.) to phenanthrene and pyrene. International Journal of Phytoremediation. Vol. 10 (2). P. $106-118$.

[9] Marumo, K., and Waite, J.H. 1986. Optimization of hydroxylation of tyrosine and tyrosine-containing peptides by mushroom tyrosinase. Biochimica et Biophysica Acta. Vol. 872. P. 98-103.

[10] Muratova, A., Hübner, Th., Tischer, S., Turkovskaya, O., Moder, M. and Kuschk P. 2003. Plant-rhizosphere-microflora association during phytoremediation of PAHcontaminated soil, International Journal of Phytoremediation. Vol. 5 (2). P. 137-151.

[11] Pilon-Smits E. 2005. Phytoremediation. Annual Reviews of Plant Biology. Vol. 56 P. 15-39.

[12] Sambrook, J., Fritsch, E.F., Maniatis, T. 1989. Molecular cloning : a laboratory manual . New York : Cold Spring Harbor Laboratory Press. 1659 p.

[13] Schroder, P. and Collins, C. J. 2002. Conjugating enzymes involved in xenobiotic metabolism of organic xenobiotics in plants. International Journal of Phytoremediation, Vol. 4(4). P. $247-26$.

[14] Siciliano, S.D., Goldie, H., Germida, J.J. 1998. Mechanisms of phytoremediation: biochemical and ecological interactions between plants and bacteria. Environmental Reviews. Vol. 6. P. 65-79.

[15] Singer, A.C., Crowley, D.E., Thompson, I.P. 2003.Secondary plant metabolites in phytoremediation and biotransformation. Trends in Biotechnology. Vol. 21. P. 123-130.

[16] Stiborova, M. and Anzenbacher, P. 1991. What are the principal enzymes oxidizing the xenobiotics in plants: cytochrome P-450 or peroxidase? General Physiology. Vol. 10. P. 209-216.

[17] Wolfe N.L. and Hoehamer C.F. 2003. Enzymes used by plants and microorganisms to detoxify organic compounds. In: S.C. McCutcheon, J.L. Schnoor 
(eds). Phytoremediation: Transformation and Control of Contaminants. John Wiley \& Sons. Hoboken. N.J. P. 159-187. 